Article

\title{
Eco-Efficiency of Government Policy and Exports in the Bioenergy Technology Market
}

\author{
Bongsuk Sung ${ }^{1}$, Myung-Bae Yeom ${ }^{2}$ and Hong-Gi Kim ${ }^{1, *}$ \\ 1 Department of International Business Management, Woosong University, 171, Dongdaejeon-ro, Dong-gu, \\ Daejeon 34518, Korea; bsssung@wsu.ac.kr \\ 2 Department of Economics, Chungnam National University, 99, Daehak-ro, Yuseong-gu, \\ Daejeon 34134, Korea; mbyeom@cnu.ac.kr \\ * Correspondence: khg@wsu.ac.kr; Tel.: +82-42-630-9316
}

Received: 16 June 2017; Accepted: 21 August 2017; Published: 5 September 2017

\begin{abstract}
This study investigates how the eco-efficiency of government policy-continuously implementing innovation-friendly policy based on both environmental and economic considerations-affects the export performance of bioenergy technologies, using panel data from 16 countries during 1995-2012. Various heterogeneous panel framework tests are conducted. Our panel unit root and co-integration tests, which allow for cross-sectional dependence in the panel, show that the time series data on the eco-efficiency of public support, exports, and gross domestic product (GDP) are integrated and co-integrated. We set up a panel vector error correction model (VECM) to empirically test the casual relationship among the variables examined. The long-term parameters of the variables were calculated using dynamic ordinary lease squares (DOLS). Panel difference generalized method of moments (GMM) estimations were conducted to test the short-term relationship among the variables. The results of this study therefore show that the eco-efficiency of government policy positively influences export performance in the long run, but not in the short run. The presented findings also indicate that efficiently implemented government policy plays a crucial role in achieving environmentally sound and sustainable development, showing path dependence among the eco-efficiency of government policy, exports, and GDP. We finally suggest policy implications based on the results.
\end{abstract}

Keywords: bioenergy technologies; eco-efficiency of government policy; export performance; dynamic panel approach

\section{Introduction}

Bioenergy technologies have been widely recognized as crucial for achieving environmentally sound and sustainable development in that they may meet all three areas of energy demand, namely heat, electricity, and transport fuels and chemicals [1]. This fact has forced governments to support the bioenergy technology sector to achieve environmental and economic goals by helping stem climate change and enhance exports in the growing international market. Despite such policy support, however, many bioenergy technologies remain relatively immature in that there is significant scope for further cost reductions through innovation. Hence, government policy that continuously provides incentives for firms to innovate is the most important factor behind enhancing global market performance.

The increased importance of government policy for the promotion of the renewable energy (RE) technology sector globally has created two research fields: an experimental setting for discussions about the efficiency of policy-the capacity of policy measures to induce continuous incentives for innovation creation (e.g., [2-6])—and empirical research into the link between government policy and exports (e.g., [7-12]). Although research on the measurement of the efficiency of government policy 
in the RE technology sector has improved our understanding of policy input and output factors by performing comparison, estimation, and descriptive analyses. (Comparison analysis (see [2,3,5,13-16]) focuses on the analysis of the innovation effects of RE technologies. It builds a theoretical framework for dynamic efficiency analysis and performs a comparative analysis of the dynamic efficiency of each policy measure (support scheme) based on various dimensions such as cost reductions, $R \& D$ investment, power capacity, electricity production, and power price. Estimation is used to calculate the effectiveness of policy measures in promoting electricity from RE sources, delivering RE technologies into the market, and encouraging efficient energy use [4,6,17]. Description analysis [18] uses surveys to assess the effectiveness of various policies in terms of stimulating interest in investing in innovative RE technologies.) An empirical gap remains in the current body of knowledge on this topic, which can be bridged in two ways. First, the literature tends to measure the efficiency of government policy at the conceptual level and thus does not provide quantitative indicators [19]. Second, studies fail to consider policy outputs from the environmental perspective (e.g., the reduction of the environmental burden) when evaluating the efficiency of government policy and tend to focus only on innovation issues that affect economic performance, such as cost reductions, power price cutting, power capacity enhancement, and electricity production.

Empirical studies that investigate how government policy influences biotechnology exports are traditionally based on four approaches: multivariate cross-sectional regression [10], country-level case study [20,21], descriptive analysis [9,22], and dynamic panel model [12]. (When considering the several empirical studies that tackle other RE sectors, namely wind, solar, and aggregated RE technologies [7,8,23-25], six approaches have emerged, including time series models and static and dynamic panel models.) By using these methods, studies have demonstrated the direct and positive role of government policy in export growth. However, they limit our ability to draw implications about the role of the efficiency of government policy in export growth. According to Costantini et al. [26] and Johnstone et al. [27], export growth is triggered by innovation spurred by policy support on both the supply and the demand sides, which means that government policy (policy input) is a highly resilient catalyst that forces firms to make major efforts to foster innovation (policy output) when the government continuously provides incentives and creates favorable conditions for innovation in the RE technology sector. This fact suggests that the effects of policy support on export performance need to be examined by considering both policy support (policy input) and innovation triggered by policy support at the same time.

Motivated by these matters often ignored in the literature, the current study investigates how the efficiency of government policy affects the export of bioenergy technologies. In particular, considering that RE technologies play an important role in green growth and that industrial activities and policy support consider both environmental and economic issues, the efficiency of policy needs to be measured by taking into account both environmental and economic aspects. Hence, we measure efficiency by assessing the environmental and innovation outputs relative to policy inputs and subsequently use the term "eco-efficiency of government policy" herein.

Previous researchers have proposed a relationship between efficiency and exports from three viewpoints. First, the empirical evidence presented by Cohen and Leven [28], Cohen [29], Hall and Oriani [30], and Duqi and Torluccio [31] demonstrates no systematic relationships between the amount of policy inputted to support industrial activities (e.g., research and development (R\&D) expenditure) and policy performance (e.g., market performance). This fact suggests that the efficiency of government policy is much more important than the amount of policy input in promoting industrial performance and growth [32]. Second, efficiency is closely related to productivity [33,34]. While productivity is simply the ratio of outputs produced to inputs, efficiency represents obtaining the maximum output from a given set of inputs or injecting the minimum set of inputs for a given output [35]. The highest productivity is thus achieved when the maximum output is obtained for a particular input level [34]. Hence, productivity growth encompasses changes in efficiency, and increasing efficiency raises productivity [36]. Third, studies based on heterogeneous firms trade theory (e.g., [37-39]), 
which originates from a dynamic industry model with heterogeneous firms [40] that focuses on the productivity premium derived from innovation in promoting export performance, states that export performance is positively affected by firm innovation.

The remainder of this paper is organized as follows. Section 2 proposes the theoretical background by reviewing the literature and contextualizing the relationship between the eco-efficiency of government policy and export performance of the biotechnology sector, and presents the empirical methodology for measuring the long- and short-run causal relationships between the two variables. Section 3 introduces the data used and presents the empirical results. Finally, Section 4 concludes as well as proposes policy implications and discusses the limitations of the study.

\section{Theoretical Background and Research Methodology}

The underpinnings of efficiency started with the studies of Debreu [41] and Koopmans [42], who define "static efficiency" as minimizing inputs in physical terms (e.g., coal, and barrels of oil) to produce a certain outcome at a certain point. Farrell [43] shows an empirical example of static efficiency at the agricultural sector level and highlights its relevance for economic policymakers [35]. By contrast, "dynamic efficiency" is defined as the process that occurs over time and leads to progressive improvements. For example, Diamond [44] shows that a competitive economy can reach a steady state in which there is unambiguously too much capital and that such an economy consistently invests more than it earns in profit when it is said to be dynamically inefficient. The economic concept of dynamic efficiency was extended by Kirzner [45] and North [46]. From a dynamic standpoint, an individual, company, institution, or entire economic system will be more efficient if it continuously fuels the discovery and creation of new means and values [47]. Indeed, since efficiency that continuously enhances the ability or incentive to innovate is regarded as dynamic [32], dynamic efficiency enables industries or firms to improve their performance. In this context, it is directly affiliated with the concept of entrepreneurship, which leads to breaking the status quo, creating market change, and developing competitive advantage [47]. Entrepreneurship is thus regarded as a productive factor (economic input and resources) in the sense that it provides a systemic coordinating function that facilitates the deployment of resources to their most highly valued uses [48], leading to outcomes such as patents.

However, entrepreneurial outcomes depend primarily on the rules of the game, or public policies, under which entrepreneurs operate [30]. Innovative stakeholders, including firms, are unable to exploit their full innovation potential without public intervention and tend to pursue short-term strategies, which is especially relevant for immature technologies such as RE technologies [49]. Hence, when public policy cannot consistently provide incentives and create favorable conditions for innovation, this increases the risk perception of the market potential of the technology and decreases the probability that RE technology manufacturers can access the funds necessary to finance their investments [50]. This fact suggests that inefficiency in public policy may change the risk-return relationship in the RE technology investment sector, consequently affecting investors' behaviors [51].

Nonetheless, government policy can stimulate entrepreneurship development in a number of ways [52]. For example, it can strengthen the linkages between stakeholders by implementing special and innovative mechanisms that foster academia-research-industry partnerships and by facilitating the mobility of experts from academia to industry and vice versa. It can also promote the spread of scientific interest and understanding across society as well as emphasize risk sharing by the government to significantly increase private sector investment in R\&D and technology development. Further, policy can provide a holistic approach to the complex innovation value chain by providing science and technology interventions at all levels of research, technology and manufacturing, and services in areas of socioeconomic importance.

In this context, eco-innovation, which is required to enhance economic performance while protecting the environment [53], can be promoted through government policy. According to Costantini et al. [26], both technology-push and demand-pull government support activities are drivers of eco-innovation in the biofuels sector. Eco-innovation thus leads to progress in eco-efficiency [54]. 
Hence, the eco-efficiency of government policy depends on simultaneously investing public resources in both technology-push activities to support $R \& D$ and demand-pull activities to create a market for the adoption and diffusion of new technology. These two policies that support such "upstream" and "downstream" activities can facilitate the deployment and dissemination of innovations by creating new products and processes as well as improving current ones $[55,56]$. RE technology innovation involves the manufacture of novel systems, products, or both [57], in which RE technologies are used both for technologies and for the products manufactured by them. Higher quality products (components) and technologies can often enhance efficiency by eliminating unnecessary tasks, automating certain tasks, and adjusting procedures and systems. In addition, innovation-friendly policy, which is crucial to reducing manufacturing and environmental costs, can contribute to improving a firm's competitiveness [54]. For example, it can enhance operational advantage thanks to greater resource efficiency, resulting in lower resource costs, commercialize innovations, and improve image, marketing, and stakeholder relations. This all means that the government can bolster the competitiveness of bioenergy technology enterprises in the global market by continuously implementing innovation-friendly policy based on both environmental and economic considerations. Hence, the eco-efficiency of government policy may directly and positively influence exports of bioenergy technologies.

To explore how the eco-efficiency of government policy affects exports of bioenergy technologies, the present study empirically measures changes in the efficiency of bioenergy technology policy from two main aspects. First, it considers suggestions from studies that have used Malmquist productivity growth index analysis [58], which is similar to the dynamic panel approach adopted herein, to consider the two policy instruments (technology-push and demand-pull) as input elements [2,53]. In addition, it calculates efficiency by considering economic and environmental outcomes to understand undesirable factors in efficiency evaluation $[59,60]$. Indeed, we consider eco-innovation by adding further sustainability attributes of innovations that allow bioenergy policies to reduce the environmental burden in the evaluation [61,62]. Further, this study measures the eco-efficiency of bioenergy technology policy based on Smith and Street's [63] notion of dynamic effects (i.e., path dependence), which means that contemporary inputs are, to some extent, invested for future outputs. Second, the study sets up a model to test the relationship between eco-efficiency and exports by considering the three driving factors that influence the direction and robustness of the empirical results in the existing literature. In particular, we use export performance rather than other export competitiveness indexes based on Costantini and Crespi [25], Jha [10], Sung and Song [23], and Sung [12], which show that export performance is significantly affected by public policy. We also set up dynamic models following Hirshleifer and coworkers' [64] argument that it takes time for a firm's performance growth to become evident following the enhancement of eco-efficiency. In addition, we adopt the view that path dependence processes (i.e., dynamic effects) include interactions among export performance, eco-efficiency, and GDP based on Sung [23], implying that most panel data are heterogeneous and non-stationary co-integrated. Finally, we include per-capita real GDP in the model to control for any omitted variables that may influence the relationships tested in the study. Per-capita real GDP represents the relationships between higher income [65] and the increased demand preference for and demand for exports [7,24], increased sociopolitical pressure [66], and the increased home market size of RE technologies [67].

To investigate the relationships between the eco-efficiency of government policy and export performance of bioenergy technologies, the study uses the following panel vector autoregression (VAR) model for each case, which is expressed as

$$
E X_{i t}=\alpha_{1 j}+\sum_{p=1}^{n} \beta_{i 1 p} E X_{i t-p}+\sum_{p=1}^{n} \beta_{i 2 p} E C O E_{i t-p}+\sum_{p=1}^{n} \beta_{i 3 p} G D P_{i t-p}+\eta_{i t}+\varepsilon_{i t}
$$


where $i=1, \ldots, N$ denotes the country and $t=1, \ldots, T$ denotes the time period. $\eta_{i t}$ is the country-specific effect for the $i$ th individual in the panel and $\varepsilon_{i t}$ is the disturbance term. EX is the natural $\log$ of export performance. ECOE is the natural $\log$ of the eco-efficiency of government policy. GDP is the natural log of per-capita real gross domestic product (GDP).

This study performs dynamic panel analysis to investigate the relationship between the eco-efficiency of government policy and export performance in five steps. It first confirms whether each individual time series has normality by performing the Jarque-Bera test. Next, it estimates whether the panel has structural breaks by conducting the cumulative sum of recursive residuals (CUSUM) and cumulative sum of recursive residuals of squares (CUSUMQ). Third, to detect the presence of cross-sectional dependence, this study employs the Lagrange Multiplier (LM) tests of Breusch and Pagan [68]. When $T>N$ (as is the case in this study), the test enjoys highly desirable statistical properties relative to other tests and can be used with balance and unbalanced panels alike. Fourth, this study performs panel unit root and panel co-integration tests taking into account the results of the structural break and cross-sectional dependence tests. Non-stationary panels have attracted considerable attention over the past decade in both theoretical and empirical research and a number of panel unit root tests have been proposed. Which test can be applied to test for the stationarity of panel data depends on whether the panel tests allow for structural breaks and/or cross-sectional dependence. Then, if the results of the panel unit root tests indicate that the series are non-stationary, it can be confirmed that a long-term equilibrium relationship among the variables in question is possible, by performing panel co-integration tests. In the last phase, the current study sets up an empirical model based on the results of the panel unit root tests and panel co-integration tests, whereupon panel causality tests are undertaken.

\section{Data and Empirical Analysis}

\subsection{Data Measurement and Sources}

$E X$ is the export value and ECOE is eco-efficiency, namely the change in the efficiency of government policy to support the bioenergy technology sector. Here, we use Malmquist productivity growth index analysis [58] and data envelopment analysis (DEA), a nonparametric method, under the assumption of variable returns to scale. DEA can easily handle multiple inputs and outputs and does not require assumptions about the specific functional form of the production function [69]. To estimate eco-efficiency, we use two policy input factors, namely technology-push and demand-pull activities [2,53], and two output factors, namely innovation outcomes $[25,27,64]$ and the reduction in greenhouse gas (GHG) emissions [61,62]. Moreover, R\&D expenditure, the contribution of bioenergy to total energy supply, and the number of patent applications are the respective proxies for technology-push policy [12,23,25,70], demand-pull policy [12,23], and innovation outcomes [27,71,72].

The study uses the number of patent applications and contribution of bioenergy to total energy supply measured in terms of flow. R\&D expenditure is measure as stock. The R\&D stock of country $i$ at time $t\left(R A D S_{i t}\right)$ is computed from public R\&D expenditure by using the perpetual inventory model $R A D S_{i t}=(1-\delta) R A D S_{i, t-1}+R A D_{i, t-x}$, where $\delta$ (the depreciation rate) is set at $10 \%$ and $x$ (the time lag) is set at five years [12]. Previous studies such as Bointner [72], Bosetti et al. [73], Jeon and Shin [74], Kobos et al. [75], Popp et al. [76], and Söderholm and Klaassen [77] find an appropriate depreciation rate of $2.5-20 \%$ with a $2-10$-year R\&D time lag for RE technologies. The current study assumes a five-year time lag and a depreciation rate of $10 \%$ for the R\&D stock estimation. The initial stock value is calculated by dividing the average of the first four observations of R\&D expenditure in bioenergy technologies by the sum of the R\&D depreciation rate (in this case $10 \%$ ) and an estimate of the R\&D growth rate of each country during the period, from the year (when the R\&D expenditure data are available in each country) to 2012.

To calculate eco-efficiency, this study uses country i's patents granted in year $t$, the contribution of bioenergy to total energy supply in year $t$, and total carbon dioxide emissions excluding land use 
changes and forestry (divided by 1000 people) in year $t$. Country $i$ 's R\&D stock in fiscal year ending in year $t-2$ is used $[27,64]$. As the distributions of eco-efficiency measures (e.g., Malmquist productivity growth index) are often zero, we use ECOE as the natural log of one plus this index in the model [64]. GDP is the natural log of per-capita real GDP divided by 1000 people.

The data are annual measures for 18 years during 1995-2012 for 16 Organization for Economic Co-operation and Development (OECD) countries: Australia, Austria, Canada, Denmark, Finland, France, Germany, Italy, Japan, the Netherlands, Norway, Spain, Sweden, Switzerland, the United Kingdom, and the United States. The countries and periods were selected on the grounds of data availability. Data on bioenergy technology exports for each country were obtained from the PC-TAS database released by the International Trade Centre. R\&D expenditure of bioenergy technologies for each country was taken from the Energy Technology Research and Development database of the International Energy Agency (IEA). The contribution of bioenergy to total energy supply for each country was calculated based on data taken from the IEA's Renewable and Waste Energy Supply database and the US Energy Information Administration's International Energy Statistics. Data on the patent counts for each country were obtained from the OECD Patent Statistical Database. Only patent applications deposited at the European Patent Office were included following Johnstone et al. [27]. Data on the carbon dioxide emissions for each country (i.e., divided by the real GDP of 100 million US\$) were obtained from the OECD Economic, Environmental and Social Database. The variables EX, $G D P$, and $R A D$ were calculated according to 2009 constant prices and the international PPP.

\subsection{Panel Framework Tests}

The results of the Jarque-Bera tests for normality demonstrate that virtually none of these of these series deviates substantially from the normal distribution, showing that the null hypothesis of normality cannot be rejected at the $10 \%$ significance level in each individual time series (for the results, refer to Table A1 of Appendix A). The results of the CUSUM and CUSUMQ tests conducted to confirm the stability of each individual series show that the null hypothesis of the absence of a structural break cannot be rejected at the 5\% significance level in most individual time series (exceptions include the CUSUM test results of France, the Netherlands, and Switzerland and the CUSUMQ test results of Austria and Spain in Equation (1)) (for the results, refer to Figure A1 of Appendix A). Hence, most series are stable over time.

The results of Breusch and Pagan's [68] LM test based on the fixed-effect model revealed that the null hypothesis of cross-sectional independence is rejected at the $1 \%$ significance level (Breusch-Pagan LM test of independence $=314.341, p=0.000$ ). The modified Wald test results demonstrated that the null hypothesis of homoscedasticity within cross-sectional units is rejected at the $1 \%$ significance level, showing that the modified Wald statistic for group-wise heteroscedasticity is $822.740(p=0.000)$.

Having established that the series cross-sectionally correlate, the study carries out panel unit root tests that account for the presence of cross-sectional dependence proposed by Pesaran [78]. The results of Pesaran's [78] test that include an intercept as well as those with an intercept and a linear trend for EX, ECOE, and GDP reported in Table 1 indicate that the level variables are non-stationary and that the first difference of the three variables is stationary. The results of the panel unit root tests thus suggest a long-run relationship among the variables. Hence, the current study implements the panel co-integration tests proposed by Westerlund [79] that allow for cross-sectional dependence (see Table 2). The results of Equation (1) indicate significance for all four test statistics (Gt, $\mathrm{Ga}, \mathrm{Pt}$, and $\mathrm{Pa}$ ) in the constant and for two cases (Gt and $\mathrm{Pt}$ ) in the constant and the trend. Hence, the long-run relationship is confirmed, as the null hypothesis of no co-integrating relationship is rejected in those instances. 
Table 1. Results of the panel unit root tests.

\begin{tabular}{lrrccccc}
\hline Variables & & $E \boldsymbol{X}$ & \multicolumn{1}{c}{$\Delta \boldsymbol{E X}$} & $\boldsymbol{E C O E}$ & $\Delta E C O E$ & $G D P$ & $\Delta G D P$ \\
\hline Pesaran CADF test & (A) & 0.52 & $-3.63^{* * *}$ & 1.15 & $-4.21^{* * *}$ & 2.71 & $-6.25^{* * *}$ \\
$(z[t$-bar] statistic) & (B) & -1.16 & $-4.31^{* * *}$ & 0.49 & $-6.73^{* * *}$ & 1.25 & $-7.29^{* * *}$ \\
\hline
\end{tabular}

Notes: The individual intercept and time trend are included in (A), and the individual intercept in (B). The test of the null hypothesis of non-stationarity is based on the mean of the individual Dickey-Fuller (DF) (or augmented Dickey-Fuller [ADF] $t$-statistics of each unit in the panel. To remove the cross-sectional dependence, the standard $\mathrm{DF}$ (or ADF) regressions are augmented with the cross-sectional average of lagged levels and the first differences of the individual series (covariate augmented Dickey-Fuller [CADF] statistics). The lag lengths for the panel unit root tests are based on those employed in the univariate ADF test. The normalized $z$-test statistic is calculated by using the $t$-bar statistics. ${ }^{* * *}$ denotes significance at the $1 \%$ level.

Table 2. Results of the panel co-integration tests.

\begin{tabular}{lrrcrrc}
\hline \multirow{2}{*}{ Statistics } & \multicolumn{3}{c}{ With Trend } & \multicolumn{3}{c}{ Without Trend } \\
\cline { 2 - 6 } & Value & $\boldsymbol{z}$-Value & Robust $\boldsymbol{p}$-Value & Value & $\boldsymbol{z}$-Value & Robust $\boldsymbol{p}$-Value \\
\hline $\mathrm{Gt}$ & -3.633 & -5.253 & 0.010 & -3.667 & -7.134 & 0.001 \\
$\mathrm{Ga}$ & -4.646 & 4.903 & 0.825 & -7.681 & 0.961 & 0.050 \\
$\mathrm{Pt}$ & -10.917 & -1.958 & 0.063 & -11.955 & -4.942 & 0.002 \\
$\mathrm{~Pa}$ & -3.315 & 4.341 & 0.871 & -6.100 & -0.168 & 0.096 \\
\hline
\end{tabular}

Notes: All these distributed statistics are standard-normal. The lag and lead length are set to 1 and 0, respectively. Choosing too many lags and leads can result in the deterioration of the small-sample properties of the test. To control for cross-sectional dependence, robust critical values are obtained through 5000 bootstrap replications.

\subsection{Model Specification and Empirical Test}

In the last phase, dynamic panel causality tests are conducted based on the results of the panel co-integration tests. Evidence of co-integration implies that Engle and Granger's [80] approach can be used to estimate an error correction model. Hence, this study performs dynamic panel causality tests based on the VECM to evaluate the short- and long-run causality between the variables in question. The Granger causality model among the variables in question, based on the panel VECM, can be expressed as follows:

$$
\left[\begin{array}{c}
\Delta E X_{i t} \\
\Delta E C O E_{i t} \\
\Delta G D P_{i t}
\end{array}\right]=\sum_{n-1}^{p=1}\left[\begin{array}{lll}
\beta_{11 p} & \beta_{12 p} & \beta_{13 p} \\
\beta_{21 p} & \beta_{22 p} & \beta_{23 p} \\
\beta_{31 p} & \beta_{32 p} & \beta_{33 p}
\end{array}\right]\left[\begin{array}{c}
\Delta E X_{i t-p} \\
\Delta E C O E_{i t-p} \\
\Delta G D P_{i t-p}
\end{array}\right]+\left[\begin{array}{c}
\gamma_{1 i} \\
\gamma_{2 i} \\
\gamma_{3 i}
\end{array}\right]\left[E C T_{i t-1}\right]+\left[\begin{array}{c}
\Delta \varepsilon_{1 i t} \\
\Delta \varepsilon_{2 i t} \\
\Delta \varepsilon_{3 i t}
\end{array}\right]
$$

where $\Delta$ is the first difference operator, $E X$ is the log of exports, ECOE is the natural logs of one plus the Malmquist productivity growth index that represents eco-efficiency, GDP is the log of per-capita real GDP, $E C T_{i t-1}$ is the error correction term lagged one period that comes from the lagged residuals derived from the long-run co-integrating relationship, $\beta_{i j} \mathrm{~s}$ are the short-run adjustment coefficients, and $\varepsilon_{i t} \mathrm{~s}$ are the disturbance terms assumed to be uncorrelated with each other and to have mean zero.

Having established a co-integrating relationship, it is necessary to estimate the long-run equilibrium relationship given by the error correction term. Various single estimators such as the fully modified OLS procedures (FMOLS) proposed by Pedroni [81], DOLS estimator of Kao and Chiang [82], and pooled mean group estimator (PMG) proposed by Pesaran et al. [83] can be used to estimate the long-run equilibrium coefficients. Kao and Chiang [82] demonstrate that DOLS outperforms the FMOLS estimator in terms of mean biases, while Banerjee [84] finds that despite the differences between the two methods, the estimates from both FMOLS and DOLS are asymptotically equivalent for more than 60 observations. Hence, the study performs Kao and Chiang's [82] DOLS and Pesaran and coworkers' [83] PMG procedures. The DOLS method allows for consistent and efficient estimators of the long-run relationship, which deals with the endogeneity of regressors and accounts for the integration and co-integration properties of data. The PMG procedure is an intermediate estimator that allows the short-term parameters to differ between groups while imposing the equality of the 
long-run coefficients between groups. We use both these techniques to obtain the parameter estimates of the panel error correction model for the relationship between eco-efficiency, export performance, and the control variables. In particular, we adopt DOLS to estimate the long-run parameters and PMG to estimate the long- and short-run parameters. The DOLS results can be interpreted as the long-run coefficients, expressed as the following equation (The numbers in parentheses are $t$-statistics, while the numbers in brackets indicate the standard errors):

$$
\begin{gathered}
E X-0.414 E C O E-0.863 G D P=0 \\
(4.63)[5.32](0.63)[8.59]
\end{gathered}
$$

Equation (3) shows that all the estimated coefficients of ECOE and GDP are positive and statistically significant at the $1 \%$ level. Since the variables are expressed in natural logarithms, the coefficients can be interpreted as elasticities. The ECOE elasticity estimate is 0.414 and the GDP elasticity estimate is 0.863 for export performance, suggesting that the eco-efficiency of government policy and GDP have positive effects on export performance in these 16 OECD countries.

Given that the variables are co-integrated, the PMG estimator is used to perform Granger causality tests. Table 3 reports the results of the short- and long-run Granger causality tests for the eco-efficiency of government policy-export nexus.

\begin{tabular}{|c|c|c|c|}
\hline \multicolumn{4}{|c|}{ Panel A: Arellano-Bond One-Step Difference GMM Estimation } \\
\hline \multirow{2}{*}{ Independent Variables } & \multicolumn{3}{|c|}{ Dependent Variables } \\
\hline & $\Delta E X_{i t}$ & $\triangle E C O E_{i t}$ & $\Delta G D P_{i t}$ \\
\hline$\Delta E X_{i t-1}$ & $0.476(0.058)^{* * *}$ & $-0.005(0.054)$ & $0.008(0.006)$ \\
\hline$\triangle E C O E_{i t-1}$ & $0.006(0.044)$ & $-0.050(0.082)$ & $0.020(0.012) *$ \\
\hline$\triangle G D P_{i t-1}$ & $0.963(0.154) * * *$ & $0.149(0.203)$ & $0.922(0.018)^{* * *}$ \\
\hline$E C T_{i t-1}$ & $-0.101(0.032) * * *$ & $0.213(0.080)^{* * *}$ & $0.033(0.011)^{* * *}$ \\
\hline Sargan test & $131.76[0.166]$ & $110.33[0.680]$ & $173.39[0.001]$ \\
\hline Hansen test & $14.81[1.000]$ & $13.15[1.000]$ & $15.87[1.000]$ \\
\hline$m_{1}$ & $-2.14[0.032]$ & $-2.86[0.004]$ & $-3.46[0.001]$ \\
\hline$m_{2}$ & 1.24 [0.215] & $0.61[0.545]$ & 0.85 [0.395] \\
\hline
\end{tabular}

Table 3. Panel causality tests.

\begin{tabular}{|c|c|c|c|c|}
\hline \multirow{2}{*}{\multicolumn{2}{|c|}{ Sources of Causation (Independent Variables) }} & \multicolumn{3}{|c|}{ Dependent Variables } \\
\hline & & $\Delta E X$ & $\triangle E C O E$ & $\triangle G D P$ \\
\hline \multirow{3}{*}{ Short run } & $\triangle E X$ & & 0.001 & 2.070 \\
\hline & $\triangle E C O E$ & 0.020 & & \multirow[t]{2}{*}{$2.710 *$} \\
\hline & $\triangle G D P$ & $38.780^{* * *}$ & 0.037 & \\
\hline Long run & ECT & $9.600 * * *$ & $7.100 * * *$ & $8.520 * * *$ \\
\hline \multirow{3}{*}{ Strong (Joint) } & $\triangle E X E C T$ & & $5.100 * *$ & \multirow{3}{*}{$\begin{array}{c}24.870^{* * *} \\
0.430\end{array}$} \\
\hline & $\triangle E C O E E C T$ & $2.740 *$ & & \\
\hline & $\triangle G D P E C T$ & $27.630 * * *$ & $3.170 *$ & \\
\hline
\end{tabular}

Panel B: Statistic Values for the Panel Causality Tests

Notes: Panel (A) The tests are based on one-step difference GMM estimates. ${ }^{*}, * *$, and ${ }^{* * *}$ denote the $10 \%, 5 \%$, and $1 \%$ significance levels, respectively. GMM robust standard errors are in parentheses, and $p$-values are in square brackets. The explanatory variables are assumed to be endogenous and are instrumented in GMM style [85]. Panel (B) Wald F-statistics reported. ${ }^{*}, * *$, and ${ }^{* * *}$ denote that the null hypothesis of no causation is rejected at the $10 \%, 5 \%$, and $1 \%$ significance levels, respectively.

In VECM structure 2, however, differencing introduces a simultaneity problem because the lagged endogenous variables on the right-hand side correlate with the new differenced error term. In addition, heteroscedasticity exists in the genuine errors across industries. The study deals with these problems by using Arellano and Bond's [86] difference GMM approach, where the lags in the explanatory variables at different levels are used as instruments. For the instruments to be valid, no serial correlation must exist 
among the error terms. Panel A of Table 3 shows the estimates, the Sargan [87] and Hansen [88] test results, and the $m_{1}$ and $m_{2}$ statistics. As the $m_{1}$ and $m_{2}$ statistics show, one lag is needed in VECM structure 2 to have no serial correlation in all the differenced residuals. A significant negative first-order serial correlation is found in the first differenced residuals, whereas there is no evidence of any second-order serial correlation. For the over-identifying restrictions, both Sargan's [87] test and Hansen's [88] $J$ test are conducted. However, inference is made mainly by analyzing the results of Hansen's test because the Sargan test is not robust when the number of instruments is more than the number of cross-sections (as in this case), or when there is heteroscedasticity or autocorrelation. The results of Hansen's test do not reject the validity of the instruments, thus implying the validity of the instruments used in the estimation. For VECM structure 2, the dynamic panel regression results presented in Panel A of Table 3 show no bilateral short-run relationships between $E X$ and $E C O E$, that GDP has a positive effect on $E X$, and that $E C O E$ has a negative effect on GDP. In Panel B of Table 3, the F-statistic values of the Wald test are the same as the dynamic panel regression results. The coefficient of the error correction term $(E C T)$ in the equation, wherein export is the dependent variable, is negative and significant at the $1 \%$ level, indicating that $E X$ could be a key adjustment factor for closing the gap with regard to the long-run relationship. Exports could deviate from the long-run equilibrium relationship because of particular shocks in the short run. However, in the absence of shocks, they eventually converge to the equilibrium in the subsequent period. In such a framework, long-run export dynamics are driven by both the changes in exports and the stable nature of the long-run equilibrium. The adjustment factor shows the speed of adjustment towards the equilibrium in cases that depict a deviation. The joint test results show that relationships among the variables exist, by jointly interacting with $E C T$. First, from the tests of $E C O E$ and $E C T$, the eco-efficiency of government policy affects exports jointly interacting with ECT. Second, from the tests of GDP and $E C T, G D P$ influences exports and the eco-efficiency of government policy jointly interacting with $E C T$. Finally, from tests of $E C O E$ and $E C T$, the eco-efficiency of government policy influences exports and GDP jointly interacting with ECT.

\section{Discussion and Conclusions}

This study examined the relationship between the eco-efficiency of government policy and export performance in the bioenergy technology sector, using panel data for 16 OECD countries between 1995 and 2012. It carried out heterogeneous panel framework tests, which led us to set up a panel VECM structure to empirically test the causal relationships among the variables examined. The long-term parameters of the eco-efficiency of government policy on export performance were then calculated by using DOLS. PMG estimators were also used to estimate the long- and short-run parameters by conducting Granger causality tests. Panel difference GMM estimations were further conducted to avoid correlation and endogeneity problems in the model. Then, based on the one-step difference GMM estimation results, causality was determined by running Wald tests on the coefficients of the variables.

The main results and implications from this study are as follows. First, the DOLS result indicates the existence of a positive long-run relationship between the eco-efficiency of government policy and export performance in the bioenergy sector, showing that a $1 \%$ increase in eco-efficiency would increase exports by $0.414 \%$. This study also finds evidence that short-run ECOE could be a key adjustment factor to close the gap to the long-run equilibrium between exports and the eco-efficiency of government policy, showing that the coefficient of the error correction terms in VECM structure 2, especially when exports are the dependent variable, is negative $(-0.101)$ and significant (which means that exports are adjusted by $10.1 \%$ of the past year's deviation from the equilibrium). This finding suggests that the eco-efficiency of government policy in the short run can play an important role in promoting steady and stable export growth in the long run. Hence, governments should strive to continue implementing short-run innovation-friendly policy that harmonizes with long-run industrial strategic policy in order to create reliable and positive bioenergy technology policy with regard to exports in the long term. In particular, the positive elasticity of the eco-efficiency of government policy to exports represents the importance of considering both economic and environmental aspects when formulating 
bioenergy technology policy. By taking into account that eco-efficiency relies on a continuously innovation-facilitating policy style and that eco-innovation leads to progress in eco-efficiency [54], in the long run, policymakers should aim to implement public policy that addresses eco-innovation by promoting economic performance, while protecting the environment at the same time.

Second, the joint Granger causality test (short- and long-run) in VECM structure 2, especially when exports are the dependent variable, provides evidence that the eco-efficiency of government policy positively Granger causes export growth, even though the short-run effect of eco-efficiency on exports is insignificant. This result implies that the eco-efficiency of government policy involves increasing exports jointly interacting with the error correction term. This suggests that it is possible for governments to enhance export competitiveness, by promoting environmentally sound and sustainable development in society, and increasing innovation at the same time. Hence, policy makers should, where possible, formulate eco-innovation strategies that promote export activities and industrial expansion.

Third, this study finds no evidence of a short-run causal relationship from eco-efficiency to export performance; however, there is a short-run causal relationship between the contemporaneous and one-period lagged growth of exports. This finding implies the need to consider the path dependence process of exports (i.e., learning-by-exporting effects) in the bioenergy technology sector when implementing policy. Hence, policymakers should promote exports of bioenergy technologies while creating reliable and positive short-term elasticity with regard to the eco-efficiency of government policy. In particular, international trade in bioenergy technologies tends to be both demand- and supply-driven in many countries [22], while the bioenergy technology sector is subject to influence from policies of various domains, not only energy, industrial, environmental, and competition policies [89]. Therefore, governments should adopt demand- and supply-side policy measures to enhance exports of bioenergy technologies. Furthermore, policymakers should recognize that demand for imports of bioenergy technologies in foreign countries depend heavily on mandates for GHG emissions reductions and changes in the sustainability of biofuels [22]. Hence, they must implement export promotion policy measures to ensure that the policy process is integrated into foreign countries' GHG reduction and import and production strategies in the short and long run.

Fourth, this study found a short-run causal linear relationship from GDP to exports. In particular, the results of the joint Granger causality tests (short- and long-run) in VECM structure 2 with exports as the dependent variable showed a positively bidirectional Granger causal relation between GDP and export growth. They also showed that GDP positively influences export growth in the long run and that GDP Granger causes eco-efficiency, which has positive effects on export growth in the long run. These findings suggest that a path dependence process among the eco-efficiency of government policy, exports, and GDP exists. These relations suggest that efficiently implemented government policy plays an important socioeconomic role in achieving environmentally sound and sustainable development by increasing real GDP driven by export growth. This leads to governmental budgetary slack, which allows policymakers to promote RE technologies [66] and/or increase demand preferences, demand, and consumption for RE technologies [7,25,90], which can also lead to an increase in home market size [67]. Therefore, policymakers should find effective policy responses to formulate more effective strategies that address the various connotations of real GDP related to RE technologies. In summary, a path dependence process (i.e., dynamic learning effects in exports) exists between the contemporaneous and one-period lagged growth of exports in the bioenergy technology industry. Moreover, the eco-efficiency elasticity to exports is positive. Therefore, government policy strategies that exploit the various impacts of real GDP on bioenergy technologies would promote bioenergy technologies from both the demand and the supply sides. In particular, to consider RE technologies as drivers of sustainable economic growth as well as environmental solutions, governmental policies should concentrate on domestic innovation and the diffusion of RE technologies to enhance foreign trade competitiveness [91].

Although the findings of this study enhance our understanding of the importance of the eco-efficiency of government policy in promoting exports of bioenergy technologies, future 
research could address relevant factors that are likely to affect export performance. For example, industry-specific export promotion programs enhance firms' export performance by increasing their informational and experiential knowledge, stimulating managers' positive attitudes and perceptions towards exports, and increasing export commitment [92]. Hence, further research should control for the effects of an industry-specific export promotion program in the relationship between the eco-efficiency of government policy and exports of bioenergy technologies. Further, while additional factors influence the RE technology sector, such as environmental regulations [8,25], other RE technology policies [27,91], and economic and social factors $[66,93,94]$, this study does not consider such factors. Therefore, further research should control for these omitted variables.

Acknowledgments: This study was financially supported by the National Research Foundation of Korea grant funded by the Korean government (NRF-2015S1A3A2046546).

Author Contributions: B.S., M.-B.Y., and H.-G.K. conceived and designed the research idea. B.S. analyzed the final simplified model presented in this paper. All authors have read and approved the final manuscript.

Conflicts of Interest: The authors declare no conflict of interest.

\section{Appendix A}

Table A1. Descriptive statistics.

\begin{tabular}{|c|c|c|c|c|c|c|c|c|}
\hline Country & Variable & Mean & SD & MIN & MAX & Skewness & Kurtosis & Jarque-Bera \\
\hline \multirow{3}{*}{$\mathrm{AU}$} & $E X$ & 6.330 & 0.476 & 5.730 & 7.153 & 0.326 & 1.596 & 1.679 \\
\hline & $E C O E$ & 0.468 & 0.422 & 0.000 & 1.134 & 0.092 & 1.522 & 1.571 \\
\hline & $G D P$ & 13.327 & 0.367 & 12.735 & 13.849 & -0.121 & 1.755 & 1.139 \\
\hline \multirow{3}{*}{ AUT } & $E X$ & 5.990 & 0.903 & 4.362 & 7.020 & -0.429 & 1.956 & 1.294 \\
\hline & $E C O E$ & 0.420 & 0.457 & 0.000 & 1.350 & 0.520 & 2.002 & 1.472 \\
\hline & $G D P$ & 12.489 & 0.241 & 12.124 & 12.878 & 0.554 & 1.792 & 1.041 \\
\hline \multirow{3}{*}{ CAN } & $E X$ & 6.501 & 0.624 & 5.110 & 7.284 & -0.775 & 2.828 & 1.727 \\
\hline & $E C O E$ & 0.443 & 0.414 & 0.000 & 1.508 & 0.740 & 3.517 & 1.744 \\
\hline & $G D P$ & 13.806 & 0.294 & 13.308 & 14.227 & -0.200 & 1.799 & 1.135 \\
\hline \multirow{3}{*}{ DEN } & $E X$ & 5.625 & 0.850 & 4.273 & 7.311 & 0.123 & 2.216 & 0.478 \\
\hline & $E C O E$ & 0.777 & 0.163 & 0.554 & 1.250 & 1.340 & 5.520 & $6.682 * *$ \\
\hline & GDP & 12.050 & 0.257 & 11.624 & 12.433 & -0.090 & 1.857 & 0.947 \\
\hline \multirow{3}{*}{ FIN } & $E X$ & 4.832 & 0.604 & 4.078 & 5.862 & 0.470 & 1.632 & 1.953 \\
\hline & $E C O E$ & 0.446 & 0.453 & 0.000 & 1.449 & 0.502 & 2.252 & 1.112 \\
\hline & GDP & 11.945 & 0.269 & 11.448 & 12.324 & -0.277 & 2.011 & 0.910 \\
\hline \multirow{3}{*}{ FRA } & $E X$ & 7.713 & 0.575 & 6.524 & 8.410 & -0.476 & 2.294 & 0.995 \\
\hline & $E C O E$ & 0.583 & 0.351 & 0.000 & 1.042 & -0.891 & 2.316 & 2.581 \\
\hline & $G D P$ & 14.379 & 0.241 & 13.992 & 14.732 & -0.075 & 1.766 & 1.094 \\
\hline \multirow{3}{*}{ GER } & $E X$ & 8.530 & 0.695 & 7.259 & 9.386 & -0.595 & 2.230 & 1.423 \\
\hline & $E C O E$ & 0.758 & 0.092 & 0.575 & 0.875 & 0.141 & 2.180 & 1.233 \\
\hline & $G D P$ & 14.736 & 0.206 & 14.434 & 15.071 & -0.358 & 1.765 & 2.135 \\
\hline \multirow{3}{*}{ ITA } & $E X$ & 7.527 & 0.444 & 6.833 & 8.129 & 0.026 & 1.430 & 1.748 \\
\hline & ECOE & 0.624 & 0.377 & 0.000 & 1.390 & -0.156 & 2.833 & 0.089 \\
\hline & GDP & 14.292 & 0.217 & 13.924 & 14.601 & -0.184 & 1.851 & 1.030 \\
\hline \multirow{3}{*}{ JPN } & $E X$ & 8.440 & 0.380 & 7.588 & 8.907 & -0.863 & 2.958 & 2.115 \\
\hline & $D G E$ & 0.511 & 0.357 & 0.000 & 0.943 & -0.601 & 1.750 & 2.131 \\
\hline & GDP & 15.217 & 0.049 & 15.139 & 15.299 & 0.216 & 1.790 & 1.168 \\
\hline \multirow{3}{*}{ NED } & $E X$ & 7.4682 & 1.055 & 4.909 & 8.176 & -1.090 & 3.642 & 3.661 \\
\hline & $E C O E$ & 0.681 & 0.431 & 0.000 & 1.499 & -0.205 & 2.401 & 0.373 \\
\hline & GDP & 13.188 & 0.294 & 12.664 & 13.596 & -0.270 & 1.950 & 0.973 \\
\hline \multirow{3}{*}{ NOR } & $E X$ & 4.807 & 1.103 & 2.276 & 6.392 & -0.914 & 3.177 & 2.392 \\
\hline & $E C O E$ & 0.530 & 0.420 & 0.000 & 1.332 & 0.060 & 2.019 & 0.692 \\
\hline & $G D P$ & 12.165 & 0.395 & 11.515 & 12.736 & -0.205 & 1.788 & 1.159 \\
\hline \multirow{3}{*}{ ESP } & $E X$ & 6.140 & 0.822 & 4.434 & 7.369 & -0.243 & 2.347 & 0.469 \\
\hline & $E C O E$ & 0.527 & 0.371 & 0.000 & 0.915 & -0.648 & 1.612 & 2.556 \\
\hline & $G D P$ & 14.838 & 0.369 & 13.222 & 14.272 & -0.276 & 1.665 & 1.477 \\
\hline
\end{tabular}


Table A1. Cont.

\begin{tabular}{llrlrrrrc}
\hline Country & Variable & Mean & SD & MIN & MAX & Skewness & Kurtosis & Jarque-Bera \\
\hline \multirow{3}{*}{ SUI } & $E X$ & 5.993 & 0.650 & 4.529 & 6.797 & -0.738 & 2.587 & 1.665 \\
& $E C O E$ & 0.732 & 0.464 & 0.000 & 1.822 & 0.499 & 3.225 & 0.742 \\
& $G D P$ & 12.573 & 0.253 & 12.180 & 12.964 & 0.031 & 1.829 & 0.973 \\
\hline \multirow{3}{*}{ SWI } & $E X$ & 6.413 & 0.387 & 5.566 & 6.992 & -0.878 & 3.323 & 2.261 \\
& $E C O E$ & 0.670 & 0.421 & 0.000 & 1.532 & -0.307 & 2.350 & 0.473 \\
& $G D P$ & 12.560 & 0.247 & 12.220 & 12.977 & -0.362 & 1.875 & 1.126 \\
\hline \multirow{3}{*}{ UK } & $E X$ & 7.492 & 0.436 & 6.438 & 8.052 & -1.126 & 3.808 & 4.062 \\
& $E C O E$ & 0.664 & 0.417 & 0.000 & 1.566 & 0.189 & 3.248 & 0.146 \\
& $G D P$ & 14.362 & 0.277 & 13.884 & 14.786 & -0.144 & 1.910 & 0.899 \\
\hline \multirow{3}{*}{ USA } & $E X$ & 8.529 & 0.642 & 7.354 & 9.497 & -0.016 & 1.950 & 0.781 \\
& $E C O E$ & 0.744 & 0.126 & 0.511 & 1.005 & -0.093 & 2.850 & 0.040 \\
& $G D P$ & 16.217 & 0.284 & 15.723 & 16.632 & -0.236 & 1.865 & 1.069 \\
\hline
\end{tabular}

Notes: The country codes AU, AUT, CAN, DEN, FIN, FRA, GER, ITA, JPN, NED, NOR, ESP, SUI, SWI, UK, and USA denote Australia, Austria, Canada, Denmark, Finland, France, Germany, Italy, Japan, The Netherlands, Norway, Spain, Sweden, Switzerland, the United Kingdom and the United States of America, respectively. ${ }^{* *}$ denotes significance at the $5 \%$ level. The null hypothesis is normality.

Australia

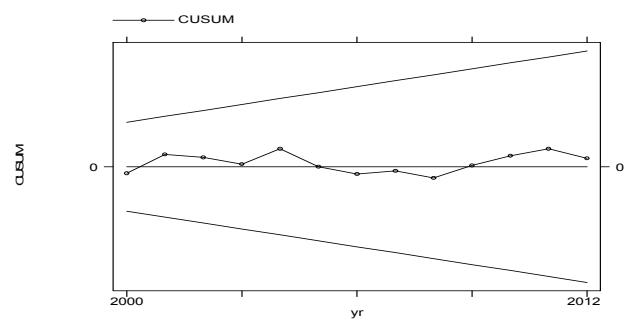

Austria

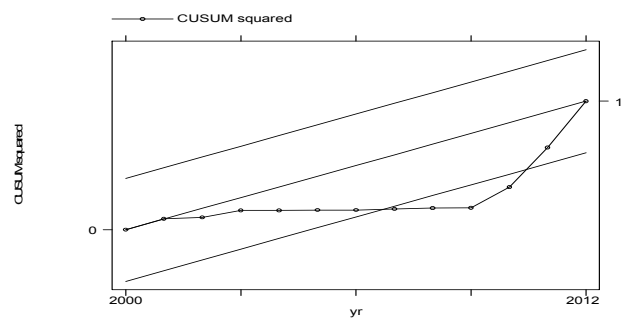

Canada

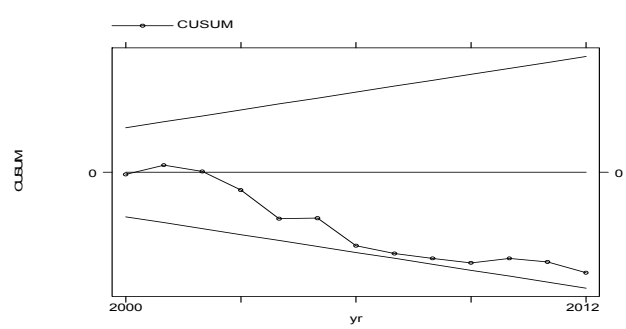

Denmark

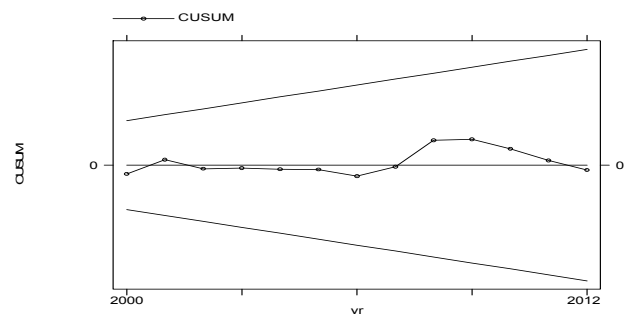

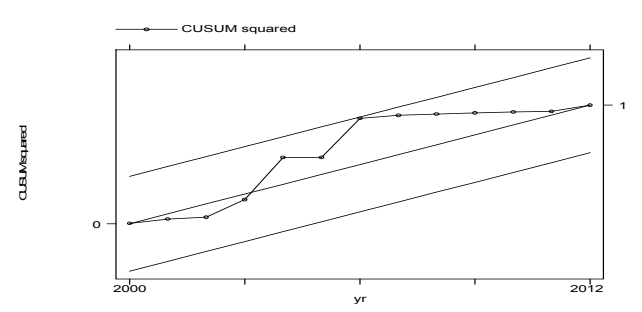
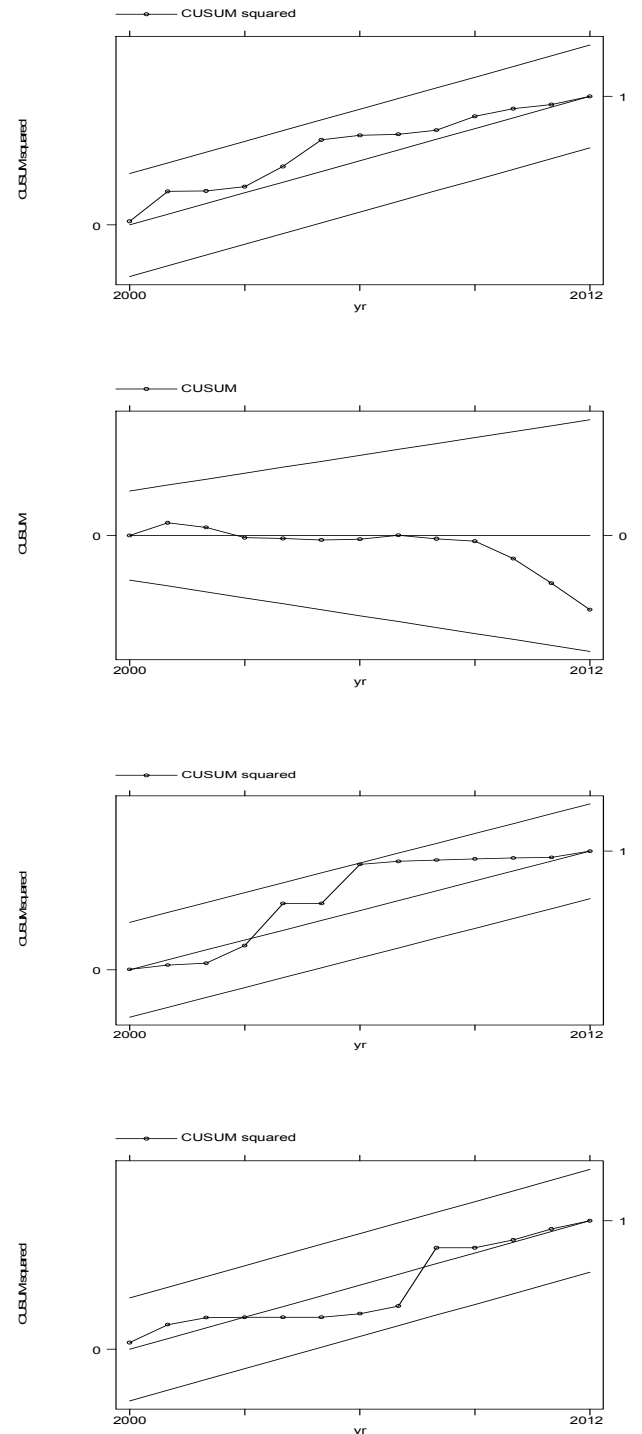

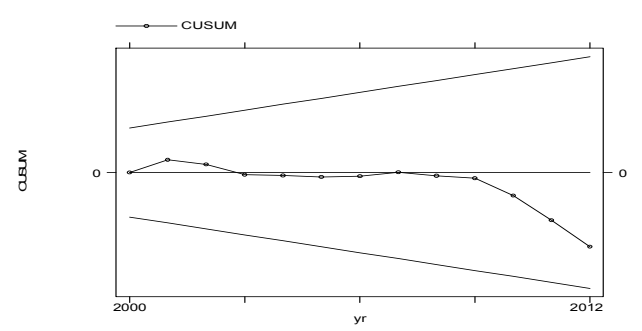

Figure A1. Cont. 
Finland
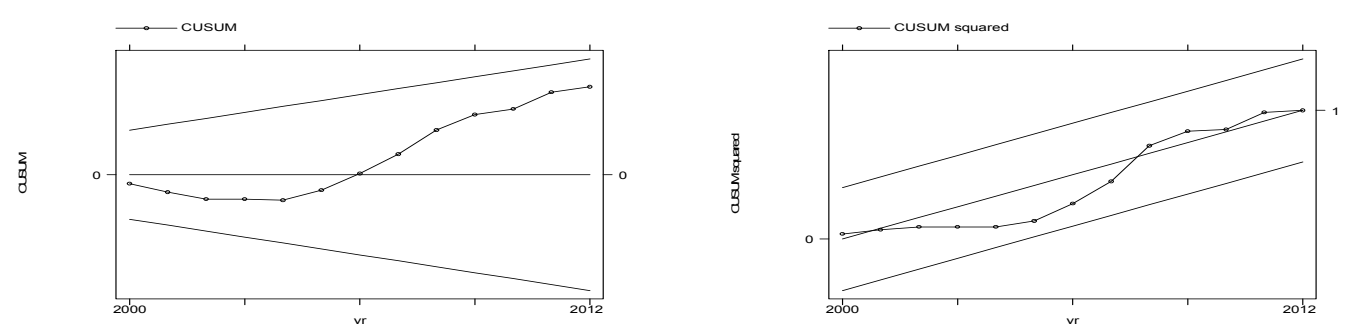

France
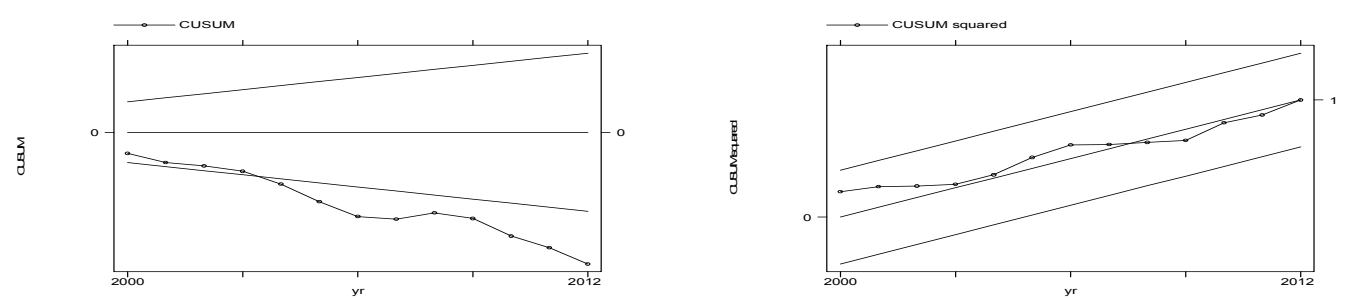

\section{Germany}
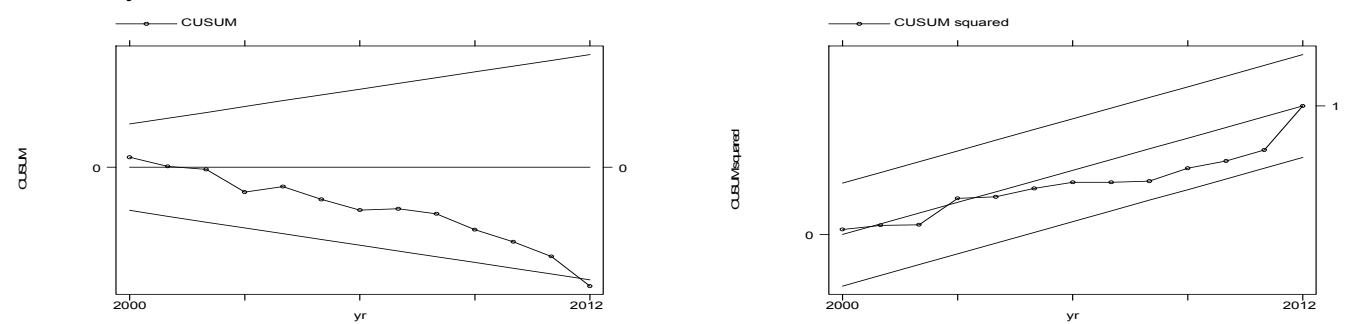

Italy
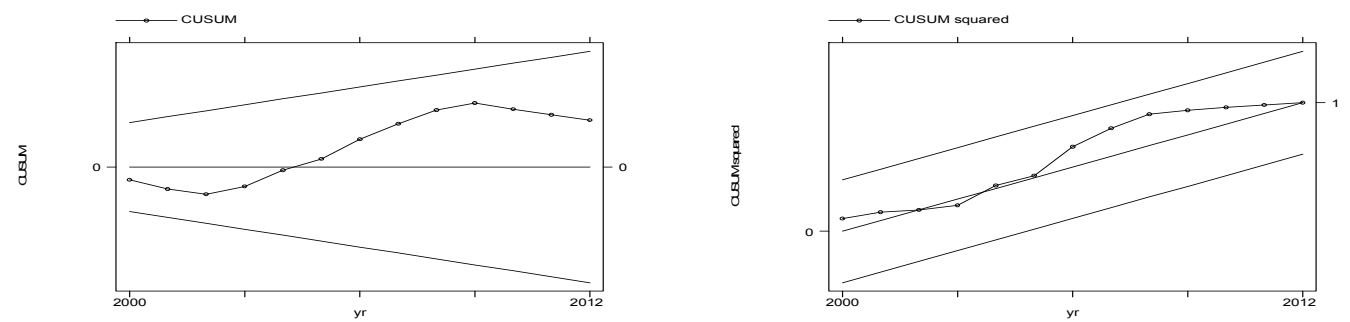

Japan
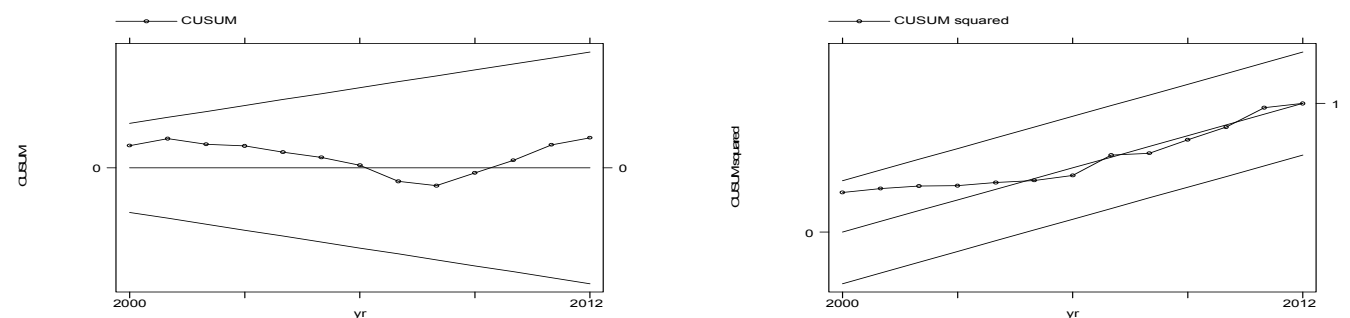

The Netherlands
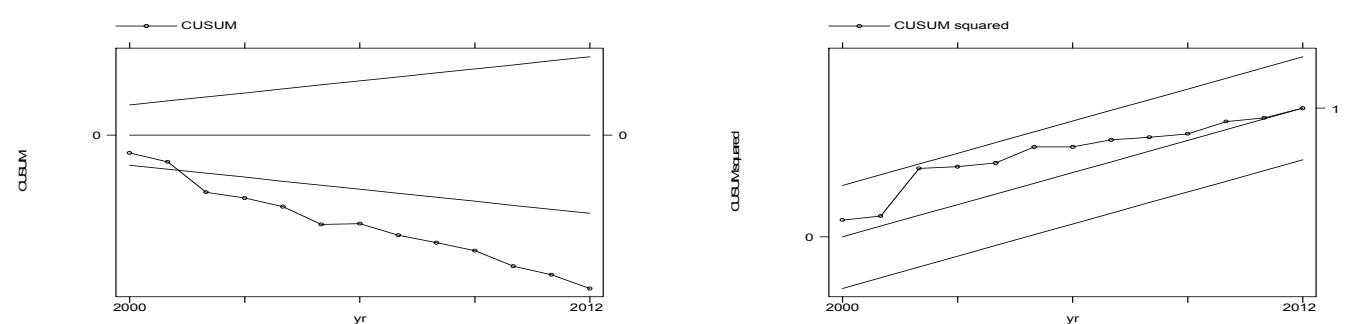

Figure A1. Cont. 
Norway
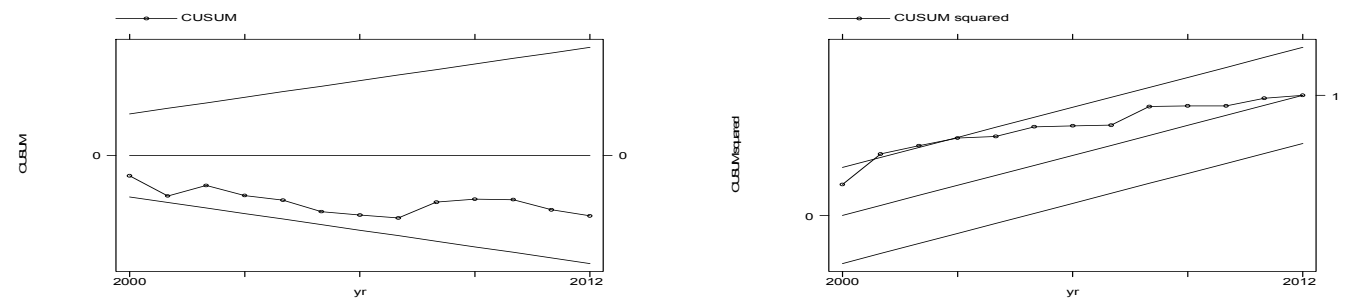

Spain
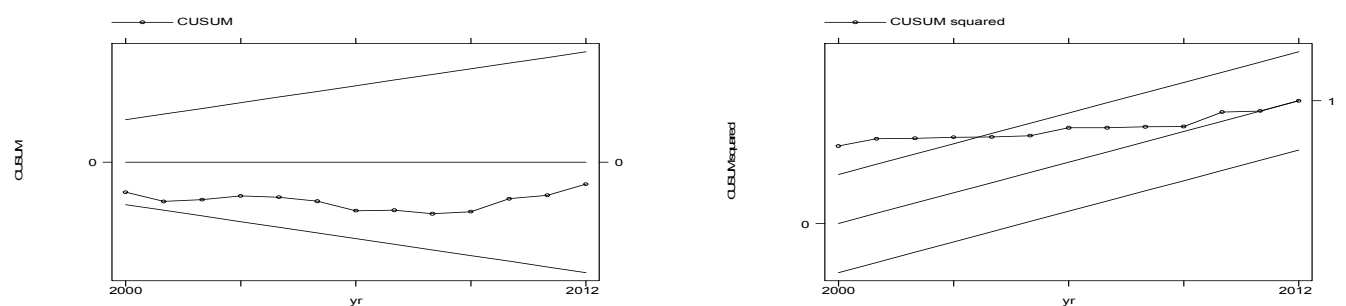

Sweden
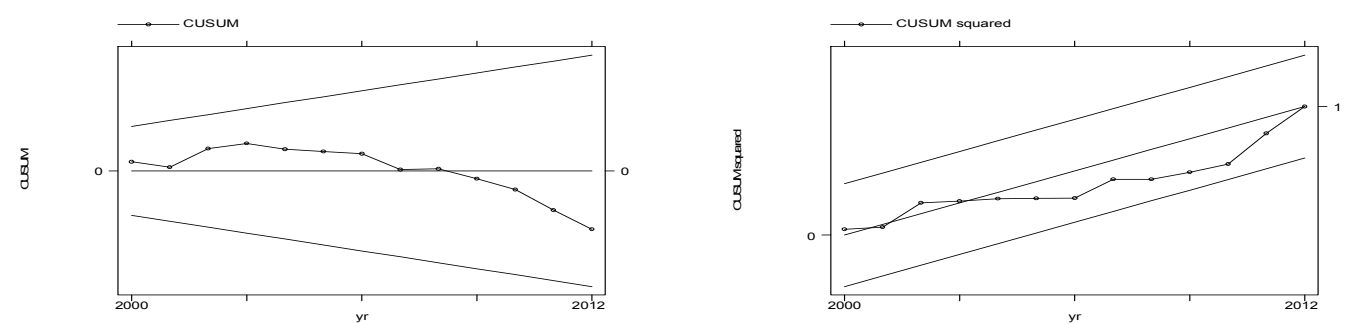

Switzerland
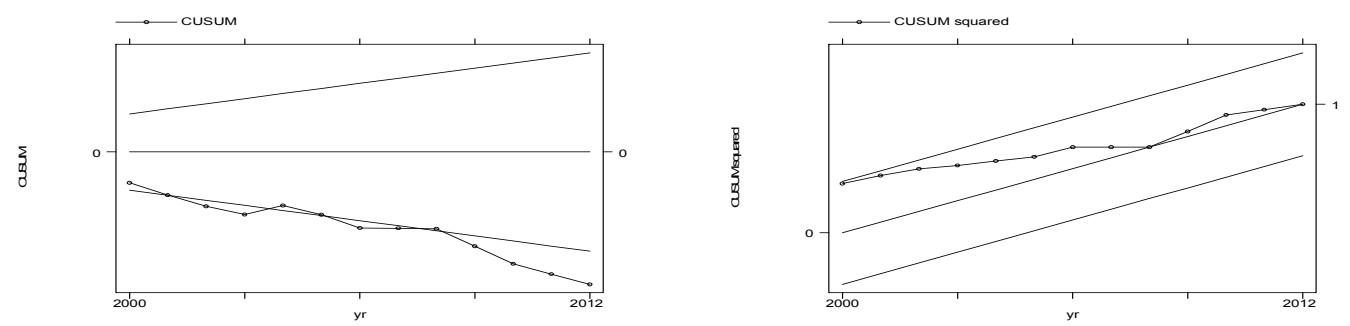

UK
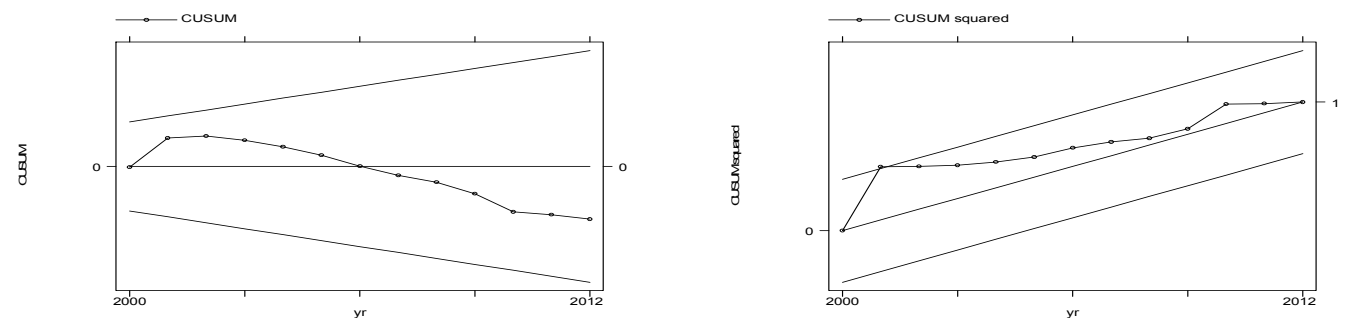

USA
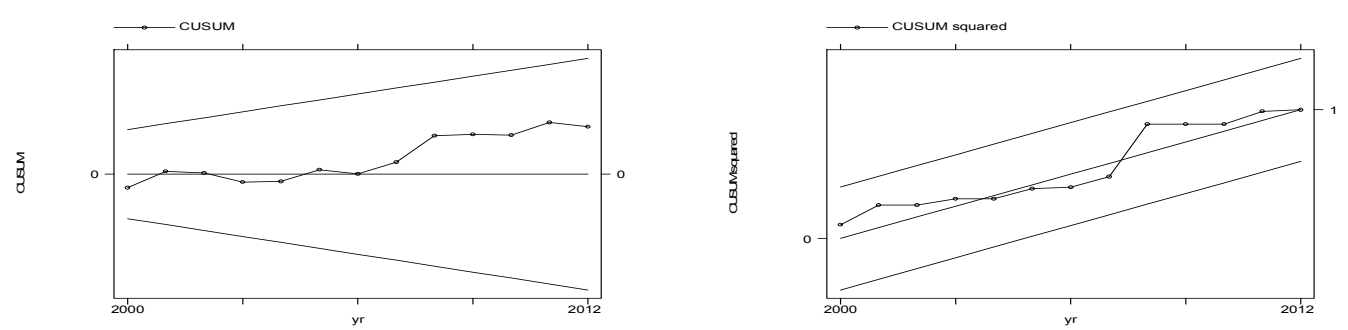

Figure A1. CUSUM and CUSUMQ tests for structural breaks. 


\section{References}

1. Jeffers, R.F.; Jacob, J.J.; Search, E.M. Dynamic analysis of policy drives for bioenergy commodity markets. Energy Policy 2013, 52, 249-263. [CrossRef]

2. Del Río, P. The dynamic efficiency of feed-in tariffs: The impact of different design elements. Energy Policy 2012, 41, 139-151. [CrossRef]

3. Menanteau, P. Can negotiated agreements replace efficiency standards as an instrument for transforming the electrical appliance market? Energy Policy 2003, 31, 827-835. [CrossRef]

4. Held, A.; Hass, R.; Ragwitz, M. On the success of policy strategies for the promotion of electricity from renewable energy sources in the EU. Energy Environ. 2006, 17, 849-868. [CrossRef]

5. Hass, R.; Resh, G.; Panzer, C.; Busch, S.; Ragwitz, M.; Held, A. Efficiency and effectiveness of promotion systems for electricity generation from renewable energy sources: Lessons from EU countries. Energy 2011, 36, 2186-2193. [CrossRef]

6. Klessmann, C. Status and perspectives of renewable energy policy and deployment in the European Union: What is needed to reach the 2020 targets? Energy Policy 2011, 39, 7631-7657. [CrossRef]

7. Cao, J.; Groba, F. Chinese Renewable Energy Technology Exports: The Role of Policy Innovation and Markets; Discussion Papers No. 1263; German Institute for Economic Research: Berlin, Germany, 2013.

8. Costantini, V.; Mazzanti, M. On the green and innovative side of trade competitiveness? The impact of environmental policies and innovation on EU Exports. Res. Policy 2012, 41, 132-153. [CrossRef]

9. Junginger, M.; Bolkesjø, T.; Bradley, D.; Dolzan, P.; Faaij, A.; Heinimö, J.; Hektor, B.; Leistad, Ø.; Ling, E.; Perry, M.; et al. Developments in international bioenergy trade. Biomass Bioenergy 2008, 32, 717-729. [CrossRef]

10. Jha, V. Trade Flows, Barriers and Market Drivers in Renewable Energy Supply Goods: The Need to Level the Playing Field; ICTSD Trade and Environment Issue Paper 10; International Centre for Trade and Sustainable Development: Geneva, Switzerland, 2009.

11. Larmers, P. Developments in international solid biofuel trade: An analysis of volumes, policies, and Market Factors. Renew. Sustain. Energy Rev. 2012, 6, 3176-3199. [CrossRef]

12. Sung, B. Public policy supports and export performance of bioenergy technologies: A dynamic approach. Renew. Sustain. Energy Rev. 2015, 24, 477-495. [CrossRef]

13. Butler, L.; Neuhoff, K. Comparison of feed-in tariff, quota and auction mechanisms to support wind power development. Renew. Energy 2008, 33, 1854-1867. [CrossRef]

14. Finon, D.; Menanteau, P. The static dynamic efficiency of instruments of promotion of renewables. Energy Stud. Rev. 2003, 12, 53-83. [CrossRef]

15. Menanteau, P.; Finon, D.; Lamy, M.-L. Prices versus quantities: Choosing policies for promoting the development of renewable energy. Energy Policy 2003, 31, 799-812. [CrossRef]

16. Toke, D. Renewable financial support systems and cost-effectiveness. J. Clean. Prod. 2007, 15, $280-287$. [CrossRef]

17. Lund, P.D. Effectiveness of policy measures in transforming the energy system. Energy Policy 2007, 35, 627-639. [CrossRef]

18. Bürer, M.J.; Wüsternhagen, R. Which renewable energy policy is a venture capitalist's best friend? Empirical evidence from a survey of international cleantech investors. Energy Policy 2009, 37, 4997-5006. [CrossRef]

19. Verbruggen, A.; Lauber, V. Assessing the performance of renewable electricity support instruments. Energy Policy 2012, 45, 635-644. [CrossRef]

20. Ericsson, K.; Huttunen, S.; Nilsoon, L.J.; Svenningsson, P. Bioenergy policy and market development in Finland and Sweden. Energy Policy 2004, 32, 1707-1721. [CrossRef]

21. Junginger, M. International bioenergy trade in the Netherlands. Biomass Bioenergy 2008, 32, $672-687$. [CrossRef]

22. Larmers, P. International bioenergy trade-A review of past developments in the liquid biofuel market. Renew. Sustain. Energy Rev. 2011, 15, 2655-2676. [CrossRef]

23. Sung, B.; Song, W.-Y. Causality between public policies and exports of renewable energy technologies. Energy Policy 2013, 55, 95-104. [CrossRef]

24. Algieri, B.; Aquino, A.; Succurro, M. Going 'green': Trade specialization dynamics in the solar photovoltaic sector. Energy Policy 2011, 39, 7275-7283. [CrossRef] 
25. Costantini, V.; Crespi, F. Environmental regulation and the export dynamics of energy technologies. Ecol. Econ. 2008, 66, 447-460. [CrossRef]

26. Costantini, V.; Crespi, F.; Martini, C.; Pennacchio, L. Demand-pull and technology-push public support for eco-innovation: The case of the biofuels sector. Res. Policy 2015, 44, 577-595. [CrossRef]

27. Johnstone, N.; Haščič, I.; Popp, D. Renewable energy policies and technological innovation: Evidence-based on patent counts. Environ. Resour. Econ. 2010, 5, 133-155. [CrossRef]

28. Cohen, W.M.; Levin, R.C. Empirical studies of innovation and market structure. In Handbook of Industrial Organization Volume 2; Schmalensee, R., Willig, R., Eds.; Elsevier: Amsterdam, The Netherlands, 1989; pp. 1059-1107.

29. Cohen, W. Empirical studies of innovative activity. In Handbook of the Economics of Innovation and Technological Change; Stoneman, P., Ed.; Blackwell: Oxford, UK, 1995; pp. 182-264.

30. Hall, B.H.; Oriani, R. Does the market value R\&D investment by European firms? Evidence from a panel of manufacturing firms in France, Germany, and Italy. Int. J. Ind. Organ. 2006, 24, 971-993.

31. Duqi, A.; Torluccio, G. Can R\&D expenditures affect firm market value? An empirical analysis of a panel of European listed firms. In Bank Performance Risk and Firm Financing; Molyneux, P.M., Ed.; Palgrave Macmillan: England, UK, 2011; pp. 215-241.

32. OECD. Dynamic Efficiencies in Merger Analysis; OECD: Paris, France, 2007.

33. Baily, M.N.; Chakrabarti, A.K. Innovation and the Productivity Crisis; The Brookings Institution: Washington, DC, USA, 1998.

34. Jayamaha, A.; Mula, J.M. Productivity and efficiency measurement technologies: Identifying the efficiency of techniques for financial institutions in developing countries. J. Emerg. Trends Econ. Manag. Sci. 2011, 2, 454-460.

35. Mandl, U.; Dierx, A.; Ilzkovitz, F. The Effectiveness and Efficiency of Public Spending; Economics Paper 301; Economic and Financial Affairs, European Commission: Brussels, Belgium, 2008.

36. Rogers, M. The Definition and Measurement of Productivity; Working Paper 9/98; Melbourne Institute of Applied Economics and Social Research: Melbourne, Australia, 1998.

37. Bernard, A.B.; Jensen, J.B.; Redding, S.J.; Schott, P.K. Firms in international trade. J. Econ. Perspect. 2007, 21, 105-130. [CrossRef]

38. Costantini, J.; Melitz, M. The dynamics of firm-level adjustment to trade liberalization. In The Organization of Firms in a Global Economy; Helpman, E., Marin, D., Verdier, T., Eds.; Harvard University Press: Cambridge, MA, USA, 2007; pp. 15-36.

39. Mayer, T.; Melitz, M.J.; Ottaviano, G.I.P. Market size, competition, and the product mix of exporters. Am. Econ. Rev. 2014, 104, 495-536. [CrossRef]

40. Melitz, M.J. The impact of trade on intra-industry reallocations and aggregate industry productivity. Econometrica 2003, 71, 1695-1725. [CrossRef]

41. Debreu, E. The coefficient of resource utilization. Econometrica 1951, 19, 273-292. [CrossRef]

42. Koopmans, T.C. Analysis of production as an efficient combination of activities. In Activity Analysis of Production and Allocation; Koopmans, T.C., Ed.; Wiley: New York, NY, USA, 1951; pp. 33-97.

43. Farrell, M.J. The measurement of productive efficiency. J. R. Stat. Soc. 1957, 120, 253-290. [CrossRef]

44. Diamond, P. National debt in a neoclassical growth model. Am. Econ. Rev. 1965, 55, 1126-1150.

45. Kirzner, I. How Markets Work: Disequilibrium, Entrepreneurship and Discovery; Hobart Paper, No. 133; Institute of Economic Affairs: London, UK, 1997.

46. North, D.C. Understanding the Process of Economic Change; Institute of Economic Affairs: London, UK, 1999.

47. De Soto, J. The Theory of Dynamic Efficiency; Routledge: New York, NY, USA, 2009.

48. Lewin, P. Entrepreneurial opportunity as the potential to create value. Rev. Austrian. Econ. 2015, 28, 1-15. [CrossRef]

49. Kahouli-Brahmi, S. Testing for the presence of some features of increasing returns to adoption for factors in energy system dynamics: An analysis via the learning curve approach. Ecol. Econ. 2009, 68, 1195-1212. [CrossRef]

50. Corsatea, T.D.; Giaccaria, S.; Arántegui, R.L. The role of sources of finance on the development of wind energy. Renew. Energy 2014, 66, 140-149. [CrossRef]

51. Zang, D.; Cao, H.; Zou, D. Exuberance in China's renewable energy investment: Rationality, capital structure and implications with firm level evidence. Energy Policy 2016, 95, 468-478. [CrossRef] 
52. Abhyankar, R. The government of India's role in promoting innovation through policy initiatives for entrepreneurship development. Technol. Innov. Manag. Rev. 2014, 4, 11-17.

53. Del Río, G.P. Policy implications of potential conflicts between short-term and long-term efficiency in $\mathrm{CO}_{2}$ emissions abatement. Ecol. Econ. 2008, 65, 292-303. [CrossRef]

54. Kemp, R.; Andersen, M.M. Strategies for eco-efficiency innovation. In Strategy Paper for the EU Informed Environmental Council Meeting; Ministry for Social Building, Resional Planning, and Environmental Administration: Den Haag, The Netherlands, 2004.

55. Christiansen, A.C. Technological Change and the Role of Public Policy: An Analytical Framework for Dynamic Efficiency Assessments; FIN Report 4/2001; The Fridtjof Nansen Institute: Lysaker, Norway, 2001.

56. Rosenberg, N. Inside the Black Box: Technology and Economics; Cambridge University Press: Cambridge, UK, 1982.

57. Ferroukhi, R.; Khalid, A.; García-Baños, C.; Renner, M. Renewable Energy and Jobs-Annual Review 2015; International Renewable Energy Agency: Abu Dhabi, UAE, 2015.

58. Färe, R.; Grosskopf, S.; Norris, M.; Zhang, Z. Productivity growth, technical progress and efficiency change in industrialized countries. Am. Econ. Rev. 1994, 84, 66-83.

59. Chung, Y.; Färe, R.; Grosskopf, S. Productivity and undesirable outputs: A directional distance function approach. J. Environ. Manag. 1997, 51, 229-240. [CrossRef]

60. Färe, R.; Grosskopf, S. Model undesirable factors in efficiency evaluation: Comment. Eur. J. Oper. Res. 2004, 157, 242-245. [CrossRef]

61. Dyckhoff, H.; Allen, K. Measuring ecological efficiency with data envelopment analysis (DEA). Eur. J. Oper. Res. 2001, 132, 312-325. [CrossRef]

62. Ramli, N.A.; Munisamy, S. Eco-efficiency in greenhouse emissions among manufacturing industries: A Range Adjusted Measure. Econ. Model. 2015, 47, 219-227. [CrossRef]

63. Smith, P.C.; Street, A. Measuring the efficiency of public services: The limits of analysis. J. R. Stat. Soc. 2005, 168, 401-417. [CrossRef]

64. Hirshleifer, D.; Hsu, P.-H.; Li, D. Innovative efficiency and stock returns. J. Financ. Econ. 2013, 107, $632-654$. [CrossRef]

65. Sadorsky, P. Renewable energy consumption and income in emerging economies. Energy Policy 2009, 37, 4021-4028. [CrossRef]

66. Marques, A.C.; Fuinhas, J.A. Drivers promoting renewable energy: A dynamic panel approach. Renew. Sustain. Energy Rev. 2011, 15, 1601-1608. [CrossRef]

67. Lewis, J.; Wiser, R. Fostering a renewable energy technology industry: An international comparison of wind industry policy support mechanisms. Energy Policy 2007, 35, 1844-1857. [CrossRef]

68. Breusch, T.S.; Pagan, A.R. The LM test and its application to model specification in econometrics. Rev. Econ. Stud. 1980, 47, 239-254. [CrossRef]

69. Mihaiu, D.M.; Opreana, A.; Cristescu, M.P. Efficiency, effectiveness and performance of the public sector. Rom. J. Econ. Forecast. 2010, 4, 132-147.

70. Ek, K.; Söderholm, P. Technology learning in the presence of public R\&D: The Case of European Wind Power. Ecol. Econ. 2010, 69, 2356-2362.

71. Ayari, N.; Blazsek, S.; Mendi, P. Renewable energy innovations in Europe: Dynamic panel data approach. Appl. Econ. 2012, 44, 3135-3147. [CrossRef]

72. Bointner, R. Innovation in the energy sector: Lessons learnt from R\&D expenditures and patents in selected IEA countries. Energy Policy 2014, 73, 733-747.

73. Bosetti, V.; Carrao, C.; Massetti, E.; Sgobbi, A.; Tavoni, M. Optimal energy investment and R\&D strategies to stabilize atmospheric greenhouse gas concentrations. Resour. Energy Econ. 2009, 31, 123-137.

74. Jeon, C.; Shin, J. Long-term renewable energy technology valuation using system dynamic and Monte Carlo simulation: Photovoltaic technology case. Energy 2014, 66, 447-457. [CrossRef]

75. Kobos, P.H.; Erickson, J.D.; Drennen, T.E. Technological learning and renewable energy costs: Implications for US renewable energy policy. Energy Policy 2006, 34, 1645-1658. [CrossRef]

76. Popp, D.; Hascic, I.; Medhi, N. Technology and the diffusion of renewable energy. Energy Econ. 2011, 33, 648-662. [CrossRef]

77. Söderholm, P.; Klaassen, G. Wind power in Europe: A simultaneous innovation-diffusion model. Environ. Resour. Econ. 2007, 36, 163-190. [CrossRef] 
78. Pesaran, H.M. A simple panel unit root test in the presence of cross-section dependence. J. Appl. Econ. 2017, 22, 265-312. [CrossRef]

79. Westerlund, J. Testing for error correction in panel data. Oxf. Bull. Econ. Stat. 2007, 69, 709-748. [CrossRef]

80. Engle, R.; Granger, C.W.J. Cointegration and error correction: Representation, estimation, and testing. Econometrica 1987, 55, 251-276. [CrossRef]

81. Pedroni, P. Fully modified OLS for the heterogeneous cointegrated panels. Adv. Econ. 2000, 15, 93-130.

82. Kao, C.; Chiang, M.-H. On the estimation and inference of a cointegrated regression in panel data. Adv. Econom. 2000, 15, 179-222.

83. Pesaran, H.M.; Shin, Y.; Smith, R.P. Pooled mean group estimation of dynamic heterogeneous panels. J. Am. Stat. Assoc. 1999, 94, 621-634. [CrossRef]

84. Banerjee, A. Panel data unit roots and co-integration: An overview. Oxf. Bull. Econ. Stat. 1999, 61, 607-629. [CrossRef]

85. Roodman, D. How to extabond 2: An introduction to difference and system GMM in Stata. Stata J. 2009, 9, 86-136.

86. Arellano, M.; Bond, S. Some tests of specification for panel data: Monte Carlo evidence and an application to employment equations. Rev. Econ. Stud. 1991, 58, 277-297. [CrossRef]

87. Sargan, J. The estimation of economic relationships using instrumental variables. Econometrica 1958, 26, 393-415. [CrossRef]

88. Hansen, L.P. Large sample properties of generalized method of moment estimators. Econometrica 1982, 50, 1029-1054. [CrossRef]

89. Bauen, A.; Berndes, G.; Junginger, M.; Londo, M.; Vuille, F.; Ball, R.; Bole, T.; Chudziak, C.; Faaij, A.; Mozaffarian, H. Bioenergy: A Sustainable and Reliable Energy Source. A Review of Status and Prospects; International Energy Agency: Paris, France, 2009.

90. Al-mulali, U. Examining the bi-directional long run relationship between renewable energy consumption and GDP growth. Renew. Sustain. Energy Rev. 2003, 22, 209-222. [CrossRef]

91. Kim, K.; Kim, Y. Role of policy innovation and international trade of renewable energy technology: Empirical study of solar PV and wind power technology. Renew. Sustain. Energy Rev. 2015, 44, 717-727. [CrossRef]

92. Freixanet, J. Export promotion programs: Their impact on companies' internationalization performance and competitiveness. Int. Bus. Rev. 2012, 21, 1065-1086. [CrossRef]

93. Domac, J. Socio-economic drivers in implementing bioenergy projects. Biomass Bioenergy 2005, 28, 97-106. [CrossRef]

94. McKay, H. Environmental, economic, social and political drivers for increasing use of wood fuel as a renewable resource in Britain. Biomass Bioenergy 2006, 30, 308-315. [CrossRef] 